\title{
Accounting and Theories of Management, One Important Support of Albanian Reality to Distinguishing Financially Business Development in EU Countries
}

\author{
Prof Ass Dr. Alba Robert Dumi ${ }^{I}$ \\ Ma Lorena Alikaj ${ }^{2}$ \\ 'Prof As Dr, Dean of Graduated School"Ismail Qemali" Vlora University Albania, \\ Management Depattment \\ Management Department, Economy Faculty, Tirana University \\ Email:besialba@yahoo.com \\ ${ }^{2}$ Finance Department, "Ismail Qemali" Vlora University Albania, \\ lorenaalikaj@yahoo.com
}

Doi:10.5901/ajis/2013.v2n1p361

\section{Abstract:}

The preceding discussion of risk management strategies has neglected the possibility that a bank might simply have more equity so as to have a larger buffer against the risks that it faces. This is of course the strategy that underlies the Basle Committee's thinking about capital adequacy regulation. The problem is that as given it is not a well defined strategy at all. If we think of a bank faced with repeated risks in a dynamic context, the question is how equity can be adjusted over time. In the banking literature the arguments have generally been phrased in terms of capital regulation. Thus, for instance managers' incentives to gamble for resurrection at some point could be contained by prescribing some level of capital. Other, non-capital instruments to control risk might however be just as effective. One could think of, for instance, direct supervision instead. Generally, such measures can be accommodated within the existing, capital-focus literature.

Key words: Albanian non -profitable sector, General finance theory, Firm wide risk, Products and markets, EU financing reforms, EU standards.

World tariffs have never been this low and the EU already offers very favorable market access to poor countries. What will make a difference are non-tariff issues - such as standards, services, intellectual property rights, public procurement, and infrastructure and packaging facilities. None of this can work without political governance." said EU Trade Commissioner Karel De Gucht.

\section{Introduction}

Another motive for cross-sector consolidation is that financial segments are melting into one another, as financial institutions venture into diverse product markets (banks now also sell insurance products, for example, and insurance firms sell unit-linked products) or offer innovative, mixed products (such as investment-based mortgages). Why should there by any prudential regulation of bank equity at all? The standard argument is that depositors need to be protected against the possibility of bank failure. From a welfare theoretic perspective, the merit of this argument is unclear. First, it is not clear why statutory 
regulation is needed to protect depositors. If depositors are concerned about bank safety, won't banks have an incentive to have high equity and advertise this fact? From a public-choice perspective, I can understand that well capitalized banks may want to call for statutory regulation to eliminate the competition from under-capitalized banks.

From a welfare theoretic perspective though, we should need an additional argument to establish that unregulated quality competition on the basis of bank safety provided by bank equity would involve a market failure that needs to be corrected. In the discussion we will, for brevity, use 'supervision' to denote both regulation and supervision. A number of arguments have been put forward why financial firms are "special" and would thus merit regulation and supervision. One argument is for instance that banks are prone to bank runs, because of the nature of demand deposits. Another argument is that the general public has difficulty in assessing the viability of insurance companies, similar to banks, because they are opaque institutions. Regulators are not the only stakeholders interested in the risk profile of financial firms.

This research paper is compounded by three main parts. In the first part a general picture of the Albanian economy (without standing on monetary and fiscal issues) will be made while in the following two parts we will analyze main pillars of the Albanian financial system, trying to analyze in more details the sub-sectors of the non-banking pillar, such as capital market, insurance market as well as collective saving $\&$ investment schemes.

\section{a. Discussion of general concepts of "Management Theories to Distinguishing Financially Business Development" in foreign countries}

Many firms commit sizable resources themselves to monitor and manage risk. However, received wisdom is that in the absence of market imperfections, risk management does not add any value. The reasons for managing risk are thus based on violations of the assumptions of the Modigliani-Miller irrelevance theorems. Trade has long been considered as vital for a country's development. One needs only to look at the rise of emerging economies like India, China and Brazil to see the impact that tradedriven development can have. Millions have been lifted out of poverty. Yet, while showing positive growth and increased trade, some other developing countries have been further marginalized in an increasingly competitive global landscape.

The development and good financial position of the financial system in general and the banking sector in particular is a prerequisite for carrying out a successful financial intermediation activity. In fact, over the last decade, the banking sector has experienced a rapid development. Well-known European banking groups have entered the market, bringing about knowledge and best technologies, as well as enhancing competition in the interbank market. Also, the banks with Albanian capital have expanded their network and have properly utilized the advantages of better recognition of the domestic market.

\section{b. The loans in private sector. Management Theories and Financially Business Development}

As a result of active business development policies, the banking sector has experienced a steady growth of deposits and credit expansion. It suffices to say that at end-2004, total loan accounted for only $7 \%$ of GDP, while today it accounts for approximately $40 \%$. About two-thirds of loans are extended to the private sector, while the rest to households and individuals. In business sector, loans are extended to the most important and fast-growing sectors, such as trade, other services, transport and construction. Almost all business loans are extended to private sector, though recently an increase in loans for public sector's projects / investments is registered. 
They are often held back by lack of productive capacity, difficulties in diversifying their economy, poor infrastructure and export conditions. The Communication "Trade, growth and development", redefines how the EU's trade and development policy will work for the development of those poorer countries - in particular, Least Developed Countries (LDCs) - ensuring they can increasingly enjoy its benefits. Nowadays, Albanian financial system evolved considerably, despite the financial shock caused in the market by the collapse of the pyramid schemes in mid 90s. Its main pillar is banking sector with many foreign and domestic capital banks operating all over the country.

We discuss the most important digressions in turn. Given that both management and regulators are interested in the risk profile of financial firms, they have a shared interest in accurate measurement and, consecutively, management of risk. We then briefly outline measurement methods, primarily to discuss the most important hurdles that have to be taken before a firm-wide risk management system can be implemented adequately.

\section{Literature Review and Hypotheses}

Secondly, if we accept the need for statutory regulation of bank equity to protect depositors, it is not clear why we should stop short of a 100\% equity requirement. This would provide perfect protection to depositors. However, there would be no depositors left. Shall we suppose that the $8 \%$ fixed in the Basle Agreement is a compromise between the notion that 100\% would provide perfect protection and the notion that perfect protection is useless if there is nobody left to be protected?

The full extent of the problem is not always appreciated. This is mainly because traditional concepts of risk in banking stand in the way of a proper risk perception. Specifically, the traditional distinction between credit risks and market risks tends to induce an underestimate of the risks assumed when a bank holds non fungible loans and mortgages. Since interest rate risks are subsumed under market risks, the distinction between credit risks and market risks frequently leads to the view that non fungible loans and mortgages are not subject to interest rate risk. As the American S\&L's found out to their chagrin, this view is mistaken

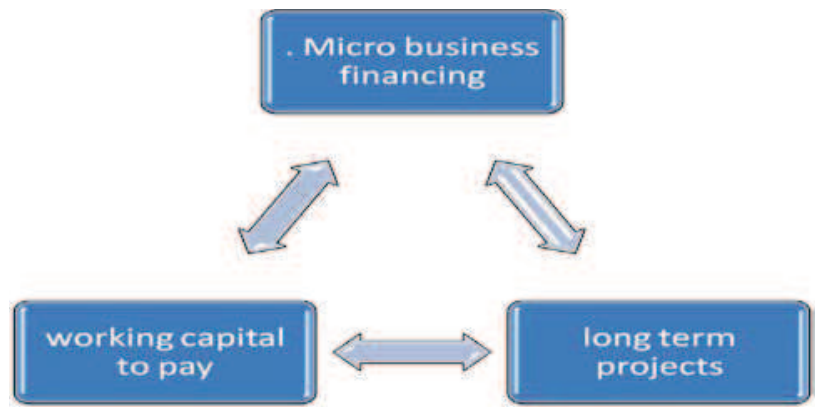

Tab I. The cycle economic developments, Source WEF-Policy 2008

In spite of weathering the direct impact of the crisis, important challenges lay ahead of the banking sector and the Bank of Albania. First, the performance of credit quality should be monitored prudentially, aiming to timely identify non-performing loans, assess them correctly according to possibilities of their repayment and pursue proper policies, in order to recover the loan value within an appropriate time. Second, during this phase, it is necessary to strengthen the banks' internal audit systems, not only related to credit risk but also to provide a higher standard of management. Third, 
banks should assess their expectations about the performance of their activity and take measures to strengthen their capital position in advance, in case of need.

Despite the low level of banking sector intermediation to the economy comparing the region, it still remains the most developed sector of the Albanian financial system. Nonetheless, on our opinion, it is a wrong perception the fact that in all country or evaluation reports made by domestic or international financial institutions, the soundness of the whole financial system is based mainly on the performance of banking sector. For this reason, this paper is an attempt to see the development Albanian financial system as a whole, focusing more on non-banking sector and analyzing the present situation together with the reasons why it remained underdeveloped. Analyzing of financial system's quantitative and qualitative performance is not subject of our study

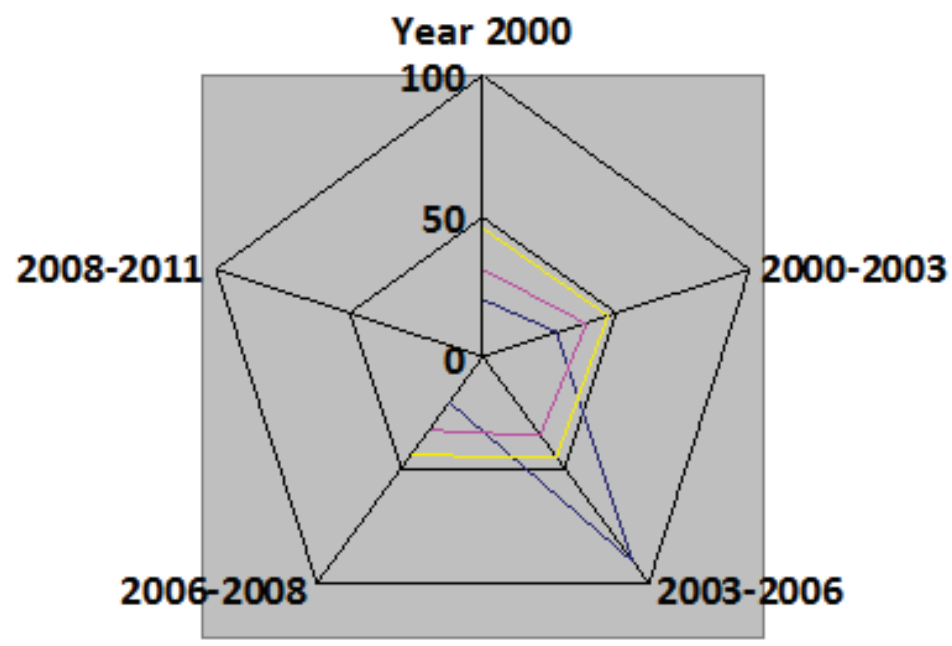

Graph I. The development Albanian financial system, source: MJSS 20II,Vol 3

It is also argued that combining banking and insurance within one organization might lead to contagion risks between sectors. These and many other arguments will be discussed: a general conclusion is that because of these arguments, supervisors are interested in the riskiness of a financial firm. A similar concern emerges from the theory on risk management, both from a market and a firm perspective. Management and the supervisor thus have a common interest in the risk profile of the firm and it's management.

We conclude with a discussion of the following question: How can a supervisor devise a framework of supervision that does justice to a financial conglomerate's own responsibility and, at the same time, safeguards the general public's interest? Input in this discussion will be our joint work with the industry concerning economic capital, a commissioned study about legal firewalls, and the discussions within the supervisory community.

\section{I Management Theories to Distinguishing Financially Business and Financial Innovations}

The discussion is based on the assumption that competitive pressures on intermediation margins are not likely to disappear, i.e., that the mechanisms which made for bank safety in the fifties and sixties are 
unlikely to be reinstalled in the foreseeable future. Financial Innovation, international financial integration, improvements in communication - all these forces, which have made for more competition since the seventies, are still at work. If anything, I should expect the intensification of competition to continue, eventually attaining also the sectors and countries that have so far remained immune. New distribution channels, including the provision of financial services through the Internet, reinforce this effect. Hence, financial institutions' activities are becoming more varied and generally more complex in nature. As their organizational structures are adapted to these developments, they too become more complex.

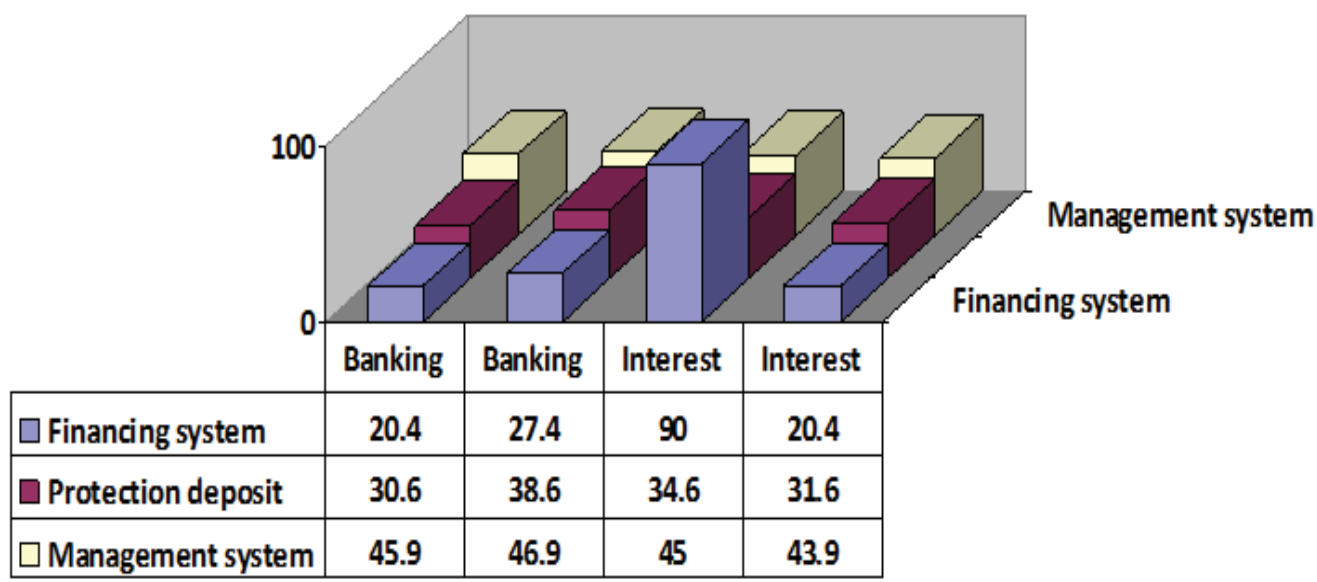

Tab 2 Remittances augment the recipients' incomes and increase their country's foreign exchange reserves.

\section{I.I Cultural constraints in economy theories (risk of borrower and risk of equity)}

The Bank of Albania deems that in the periods ahead the Albanian banking sector and the economy need to determine and pursue more suitable development policies, which should include: setting realistic development objectives; setting more competitive prices for banking products and services; and increasing lending in the national currency. About overall economy, a more sustainable development should be ensured, relating mainly to better control on trade deficit, supporting the sectors that actually contribute or may contribute to increasing exports in the country.

A typical feature of banks is that the contracts on both sides of the balance sheet have different maturities: funding is of a short-term nature, whereas lending is generally long-term. This creates both liquidity risk which is often the immediate cause of a bank run, and interest rate risk, possibly damaging solvency. Therefore public authorities must act to monitor these risks and safeguard the public interest.

Finally, banks have a pivotal role in the financial system in the clearing and settlement of transactions and - above all - providing finance, in particular to small and medium-sized enterprises. or European consumers: I.Lower prices - removing trade barriers produces healthy competition on the EU market and lower prices for consumers 2.More choice - exotic new produce from Africa, the Caribbean and the Pacific 


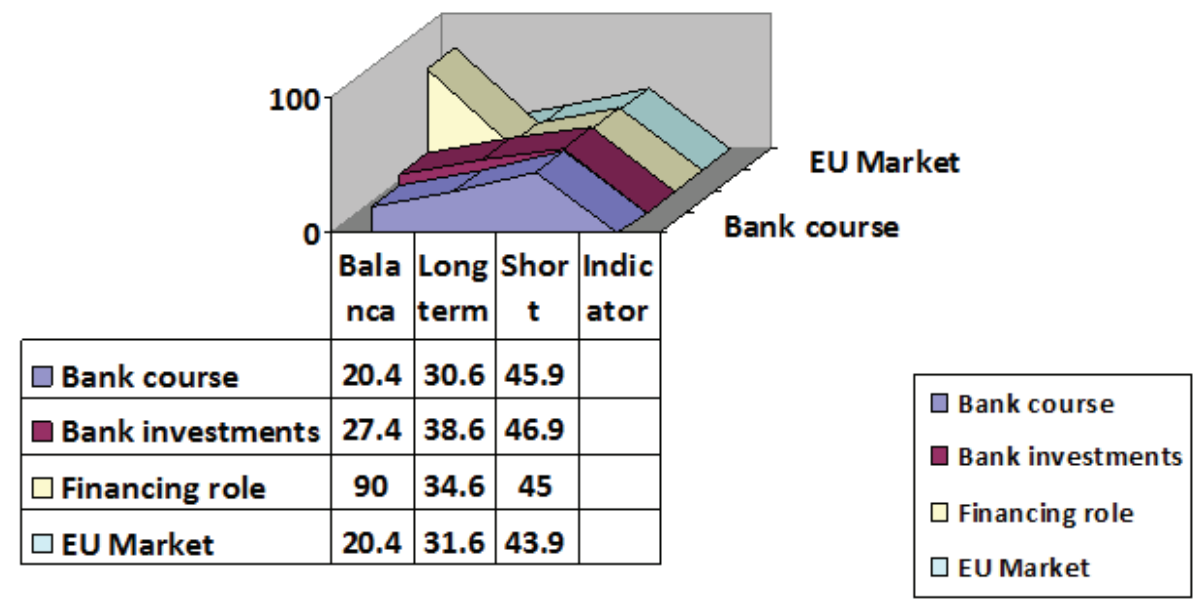

Tab 3 Financial system and settlement of transactions

Public authorities should strengthen their commitment to developing the non-bank financial market, which gradually leads to reduction of economic dependence on the banking sector condition and improves access to financing of a higher number of private entities. In this way, a greater opportunity would be provided to the financial system to finance projects in the agricultural sector, which has a high potential for ensuring competitive advantages in the Albanian economy. (Fatos I, Albanian bank 20II)

\subsection{The science of economics and general Smith concepts}

\subsection{Regulatory policies}

Regulation of financial conglomerates is changing as well. In the European community, community law supersedes national law. Once a law has been passed in the European parliament, national authorities have to enact these European laws in national legislation. Presently, the European Commission has proposed new regulation for supervision of financial conglomerates which will supplement regulation covering banking, securities, and insurance (EC (200I)

Finally, we discuss the interplay between the objectives of supervisors and the goals of financial conglomerates. Are these objectives in line with each other, or are there areas in which opposite interests are evident? In what way can supervisory regulation support the developments of firm-wide risk management systems, and is this beneficial to the industry? The main issue addressed is what the framework for coming to an adequate risk management process, and thus a satisfactory level of capital, should look like. The central tenet here is the supervised institution's responsibility in this area. The concluding section summarizes our findings. As a small business develops it moves through five growth stages, each with its own distinctive characteristics. Because the transition from one stage to the next requires change, it will be accompanied by some crisis or another.

\section{Methodology and Research Goal}

\section{I Risk Management in financial conglomerates, effects with banking insurances.}


Why manage risk? After outlining the developments that have led to the formation of large, complex, and diversified financial firms, or in other words financial conglomerates, we discuss the reasons that have been cited, mainly in the academic literature, for regulatory intervention, covering banking, insurance, and financial conglomerates in turn. In the stylized Modigliani-Miller world of corporate finance textbooks, neither the capital structure nor corporate risk management affects the value of the firm. Investors are able to diversify their invested wealth and a firm will therefore not be rewarded for taking on (or shedding) firm-specific risk. Only the remaining, non-diversifiable systemic risk carries a return. There is thus no reason for a firm to ever alter its risk profile. If market inefficiencies are introduced, however, managing risk and capital structure matter and (may) add value. Five major driving forces can be identified behind firm's risk management: (I) flow of information, (2) taxes, (3) bankruptcy costs, (4) distortions due to contracting problems between firms and investors, and (5) distorted incentives for management due to imperfect contracting between management and shareholders.

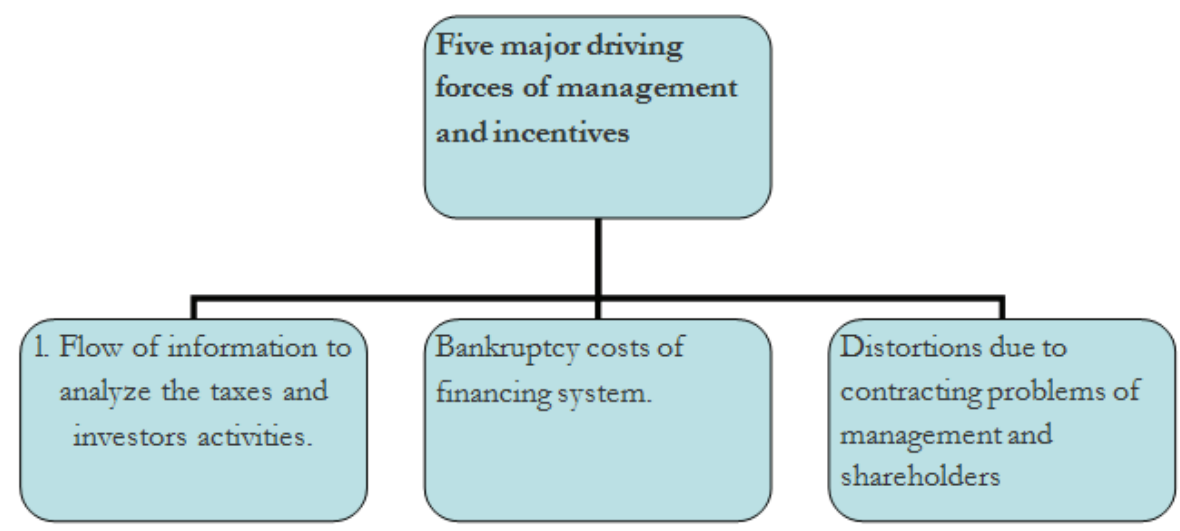

Tab 4 Five major driving forces can be identified behind firm's risk management

\subsection{Literature and Development concept}

Let us discuss these driving forces in turn.

Crises tend to be distuptive and the problems of change can be minimized if managers are proactive rather than reactive. Prior knowledge of what generates crises and what to expect in each stage will smooth the process of change. This article proposes a model of small business growth to enable managers of small businesses to plan for future growth. The model has been successfully tested and used by the authors in analyzing and solving the problem of growing small businesses. The model isolates the five growth stages, the sort of things that will precipitate crises and the major strategies that should be considered at each stage. Its main purpose is as a diagnostic tool in analyzing the firm's present position and in planning what will be required as it progresses to the next stage of its development.

\subsection{Albanian financial system and its contributes in economy activity}

The main factor threatening the soundness of the Albanian financial system is the high level of informality in the country's economy. In Albania, about half of total economic activity is considered informal. The predominance of such informality contributes to low levels of credit from the formal 
banking sector and wipes out any possibility to use capital markets as an financing alternative, as enterprises seek to avoid drawing attention to themselves from tax and other regulatory authorities. Also, governance and management remain weak in the real sector.

Private companies are often subject to poor standards of governance and management, and therefore represent serious credit risks. Business accounting practices are particularly weak, reducing bank capacity to assess creditworthiness and, consequently, their willingness to lend. The lack of professional capacity in the accounting and audit fields means full movement to IAS standards is still several years away. Strengthening internal audit functions at enterprises, ensuring the independence of auditors, enforcing a code of conduct that is consistent with international standards, and observing more open standards of transparency and disclosure would contribute to more and better information for market purposes (see Sherif at al, 2000).(Gjergji A 2006)

The new varieties of familiar goods like coffee, cocoa, mangos, pineapple etc.3.Good quality and good value - tropical products grown in tropical climates4.Jobs - in the long run, trade will help ACP countries become more prosperous. In turn, that will generate more demand for European products and expertise, which will be good for employment.5. Ethical choices - many thousands of small-scale, family-run businesses in ACP countries will benefit from being able to sell their produce in the EU.6.no quotas, no duties on exports to the EU - free access to the EU market of half a billion people for all ACP products, providing plenty of scope for economies of scale 6.no shocks - EPAs will be implemented in a way that avoids unnecessary shocks

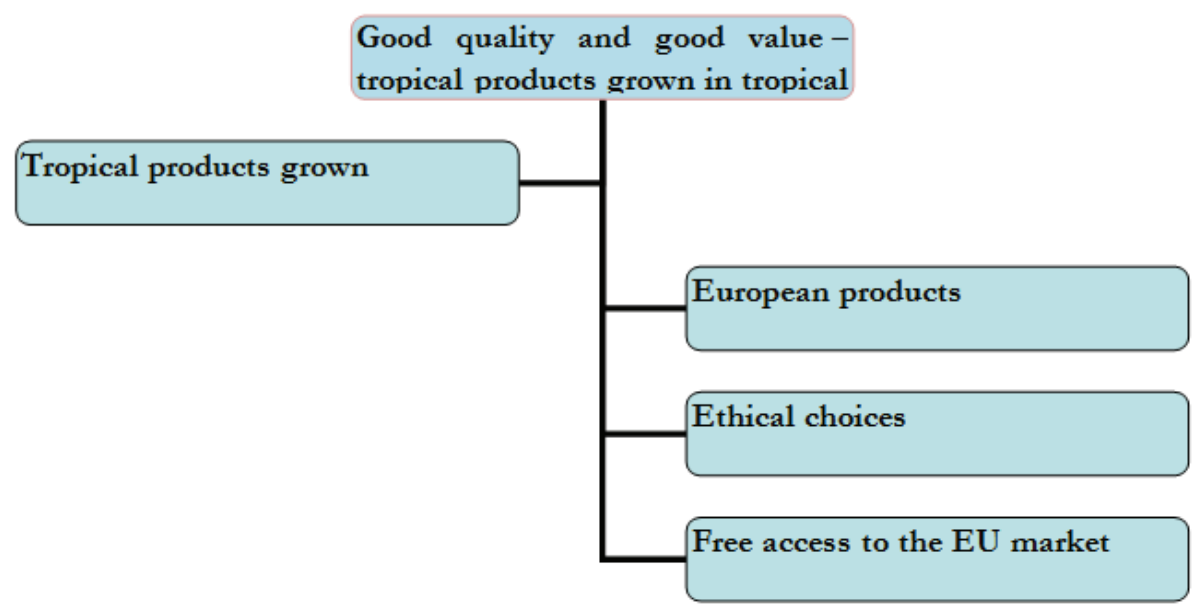

Tab 5: Identify of the indicators of the EU Market. (Gjergji A 2006)

Duties will be phased out over a period of 15 (and up to a maximum of) 25 years, with safeguards and support on offer for ACP countries that encounter problems. In this paper we are trying to identify the indicators like this:

I. Coverage of services and foreign investment - EPAs don't just deal with trade in goods but with issues relating to development too - because trade is development.

2. Wider reforms-EPAs are part of the wider development agenda for ACP countries, to strengthen the law, attract local and foreign investment and create the conditions for greater prosperity. 
3. Avoided while local industries and consumers benefit from cheaper inputs and consumer goods. Albania is one of the countries with a very high share of the foreign capital banking market.

Foreign banks here, were generally welcomed because it was shared a common feeling that they will play an important role in providing financial services essential to modernize the banking system. Foreign ownership in Albanian banks started with Banka di Roma, which was co-owner at ItalianAlbanian Bank (BIA), and then continued with prestigious foreign banks, such as: IFC, EBRD, Raiffeisen Bank (which privatized Savings Bank in April 2004), San Paolo IMI, National Bank of Greece, Bank of Piraeus etc. Banking sector in Albania is almost totally privatized. Currently, Albanian state holds only $40 \%$ of the UBA bank (relatively small bank), but as Albanian Parliament passed the law on privatizing the state share in this bank, Albanian banking system will be will be soon totally private capital owned.

The preceding discussion of the changing nature of un-diversifiable risk in banking should make us suspicious of any rigid quantification. At the very least we should have an argument as to the guiding principles underlying the choice of numbers.

HI: The reasons cited for banks are the possibility of bank runs, systemic crises, and moral hazard due to a lender of last resort and concerns regarding consumer protection. For insurance firms, the main reasons are concerns regarding consumer protection and, more generally, financial stability.

H2: What can be done, to improve the risk match between returns and obligations and to reduce the risk of bank failures and banking crises?

Any discussion of risk in banking must start from the observation that a bank's obligations to its depositors are mostly independent of the returns which the bank earns. Low realizations of returns do not reduce the bank's obligations towards its depositors. Risks are born by shareholders; to the extent that equity is insufficient, bank failure is a possibility. Certain risks in the bank's operations may be negligible because they are subject to the law of large numbers. This may, e.g., be the case for borrowerspecific default risks in small loans or for depositor-specific withdrawal risks in demand and savings deposits. It is not the case for correlated risks such as interest-induced valuation risks on long-term assets, interest-induced refinancing risks on short-term liabilities or the business cycle component of default risks on loans. In any given period these risks are not subject to the law of large numbers and there is no smoothing across customers. In the absence of contractual arrangements shifting them to another party, these risks have to be born by the bank. (Helluig M 20II)

\subsection{Financial stability and growing indicators of economy}

However, some financial stability arguments remain or even become of growing importance. First, insurers have become increasingly more intertwined with the banking sector, taking on significant amounts of credit risk. A failing insurer could thus suddenly shift sizeable amounts of risk back to the banking sector, possibly causing instability. Second, in particularly life and pension insurers have material equity holdings. Failure could imply unwinding of these positions, putting downward pressure on equity prices. In particular the expectation of a sell-off could have a relatively quick impact. Third, the stability of the insurance sector is crucial for the general confidence in the financial system and thus for economic growth. Since insurance firms supply a product with a long lifetime, disturbance of this market would have pronounced external effects (cf. Bencivenga and Smith (I99I). 


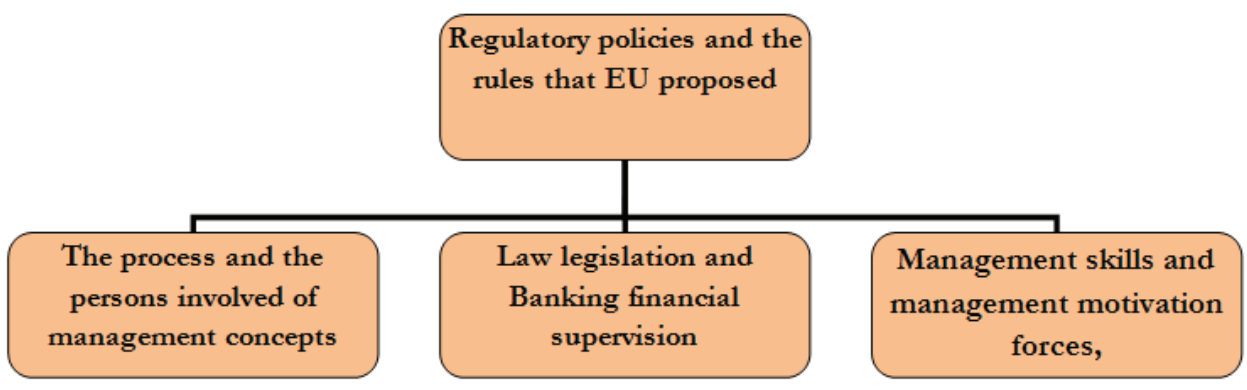

Tab 6: Cumming, C. M., and B. J. Hirtle (200I): "The Challenges of Risk Management in Diversified Financial Companies, "Federal Reserve Bank of New York, Economic Policy Review, 7, I-I7.

In principle, three types of strategies can be distinguished. Banks can try to shift un-diversifiable risks to their borrowers, e.g., by making variable-rate loans and mortgages. - Banks can try to shift undiversifiable risks to their lenders, e.g., by financing fixed-interest loans with fixed-interest obligations of similar maturities. Banks can try to shift un-diversifiable risks to third parties, e.g., through interest rate swaps or other derivative instruments. These strategies can of course be used in combination as well as separately. For the purpose of the analysis though it is easier to look at each of them in isolation

H3: The interest rate risk exposure of the system as a whole is not visible to the individual institution unless it knows that it is but an element of a cascade and that credit risks in the cascade are correlated.

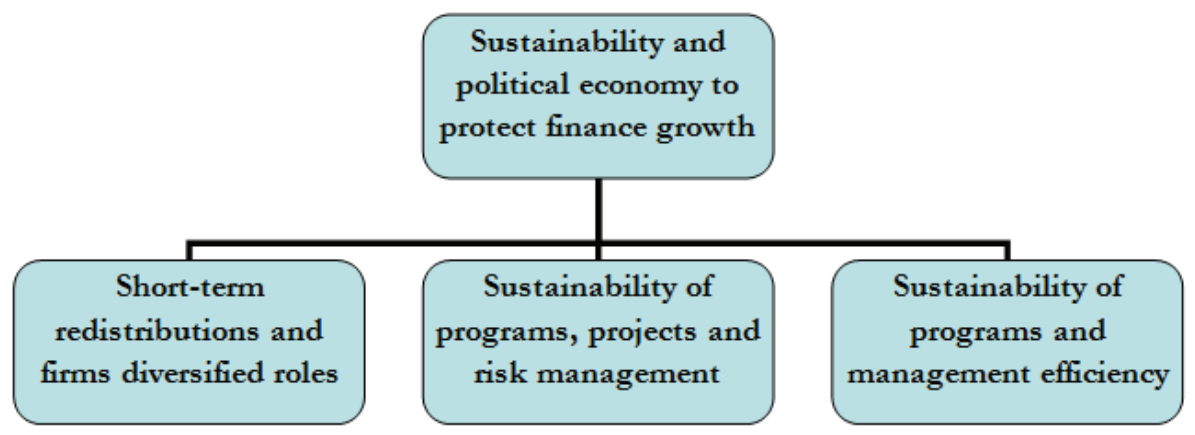

Tab 7: Chen, Y. (1999): "Banking Panics: The Role of the First-Come, First-Served Rule and Information Externalities," Journal of Political Economy, I07, 946-968.

\section{Conclusion}

Financial firms have their own reasons to care about their risk profile. In the classical world of a Miller and Modigliani textbook, the capital structure of a firm is irrelevant. If investors are interested in less risk they can reduce risk by diversifying their portfolio. The firm is thus only rewarded for that part of a firm's risks that is not diversifiable (i.e. systemic risk). Firms, however, do care about their risk profile because reality deviates from the perfect world assumed by Miller and Modigliani. Information flow, taxes, bankruptcy costs, information and incentive imperfections all supply motives for managing risk. 


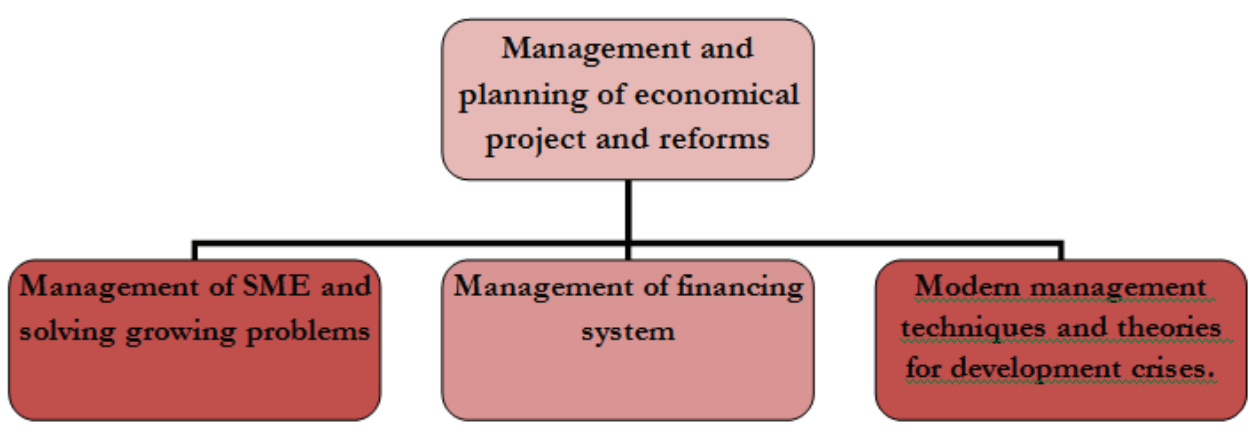

Tab 8 Management transfer to poor countries, Source: Jon Stuart Mill, 1989

Although the insurance industry is less affected than the banking industry, the credit crisis has revealed room for improvement in its risk management and supervision. Based on this observation, we formulate ten consequences for risk management and insurance regulation. Many of these reflect current discussions in academia and practice, but we also add a number of new ideas that have not yet been the focus of discussion. Among these are specific aspects of agency and portfolio theory, a concept for a controlled run-off for insolvent insurers, new principles in stress testing, improved communication aspects, market discipline, and accountability. Another contribution of this paper is to embed the current practitioners' discussion in the recent academic literature, for example, with regard to the regulation of financial conglomerates.

\section{References}

Boot, A. W. A., and A. Schmeits (2000): "Market Discipline and Incentive Problems in Conglomerate Firms with Applications to Banking," Journal of Financial Intermediation, 9, 240-73.

Brunetti, A., G. Kisunko, and B. Weder (1998): "Credibility of Rules and Economic Growth: Evidence from a Worldwide Survey of the Private Sector," World Bank Economic Review, I2, 353-84.

Bryant, J. (1980): "A Model of Reserves, Bank Runs, and Deposit Insurance," Journal of Banking \& Finance, 4, 335-344.

Chen, Y. (1999): "Banking Panics: The Role of the First-Come, First-Served Rule and Information Externalities," Journal of Political Economy, 107, 946-968.

Cumming, C. M., and B. J. Hirtle (200I): "The Challenges of Risk Management in Diversified Financial Companies, "Federal Reserve Bank of New York, Economic Policy Review, 7, I-I7.

Cummins, J. D., R. D. Phillips, and S. D. Smith (1998): "The Rise of Risk Management," Federal Reserve Bank of Atlanta Economic Review, 83, 30-40.

Diamond, D. W., and P. H. Dybvig (1983): "Bank Runs, Deposit Insurance, and Liquidity," Journal of Political Economy, 91,40I-4I9.

DNB (2002): "Structure of Financial Supervision," Quarterly Bulletin of de Nederlandsche Bank, March, 37-42. Dowd, K. (1994): "Competitive Banking, Bankers' Clubs, and Bank Regulation," Journal of Money, Credit \& Banking, 26, 289-308.

EC (200I): "Towards an EU Directive on the Prudential Supervision of Financial Conglomerates," Brussels: European Commission.

Edwards, F.R. and M.S. Canter (1995). The Collapse of Metallgesellschaft: Unhedgeable Risks, Poor Hedging Strategy, or Just Bad Luck?, Journal of Applied Corporate Finance 8, 86-I05.

Gehrig,T. (1995). Capital Adequacy Rules: Implications for Banks' Risk Taking, Discussion Paper, University of Basle, mimeo. 
Greenwald, B. and J. Stiglitz (1990).Macroeconomic Models with Equity and Credit Rationing, in: R.G. Hubbard, ed., Asymmetric Information, Corporate Finance, and

Investment, University of Chicago Press, Chicago, I5-42.

Hellwig, M. (1994a). Liquidity Provision, Banking, and the Allocation of Interest Rate Risk, European Economic Review 38, I363-I389. 